J. Perinat. Med.

3 (1975) 105

\section{Determination of fetal maturity and of development of the fetal lungs by means of combined methods}

\author{
A. Ianniruberto, F. Destro, A. Capozzi, F. Zisa, G. Cubesi, S. Parisi \\ Department of Obstetrics and Gynecology, City Hospital, Terlizzi \\ Department of Obstetrics and Gynecology, City Hospital, Gorizia, Italy
}

Received November 26, 1973. Accepted October 12, 1974.
One of the principal problems of modern obstetrics is that of estimating fetal maturity, mainly in those conditions of obstetrical pathology in which the therapeutic interruption of pregnancy is indicated.

The classical concept, according to which a fetus is considered to be mature when it has reached the gestational age of 36 weeks, is still valid.

The need for having at one's disposal parameters which are not as uncertain as the classical criteria (amenorrhoea, onset of symptoms of pregnancy, uterine development, fetal movements), has directed modern research towards the development of instrumental and laboratory techniques capable of furnishing somatic, biochemical, and cytological indices, which nowadays constitute the basic criteria for estimating gestational age and, from this, fetal maturity.

Fundamentally, these methods comprise: ultrasonic echography, which furnishes fetal somatic parameters, particularly the dimensions of the biparietal diameter (B. D.), and the biochemical, cytological, and hormonal investigation of the amniotic fluid.

The validity of ultrasonic echography, and the biological and clinical significance of the biochemical, cytological, and hormonal findings in the amniotic fluid, have been the subject of a vast body of literature $[1,2,3,4,6,7,8,9,10,11$, $13,14,16,17,18,19,20,21,23,28,29,30,33$, $34,35,39,41,42,43,44,45,46,48,49]$.

\section{Curriculum vitae}

Achille Ianniruberto is a graduate of State University Medical School in Naples, Italy. After baving completed bis residency in Obstetrics and Gynecology at Misericordia and Fordbam Hospitals in New York, US $A$, be was Attending and Chief of the Department of Obstetrics and Gynecology at Fordbam Hospital in New

York. Presently be is Director of the Department of Obstetrics and Gynecology at Terlizzi City Hospital, Italy, and Professor of Clinical Obstetrics and Gynecology at the State University of Naples.

$\mathrm{He}$ is a Fellow. of the American College of Obstetricians and Gynecologists, of the American Fertility Society and of the International College of Surgeons.

The most recent studies $[5,12,15,22,24,25,26$, $27,31,32,36,37,38,47]$ have demonstrated the value of analysis of phospholipid constituents as a specific method for estimating the degree of maturation of the fetal lung; the validity of this method has now been confirmed by numerous clinical observations, which show beyond doubt how neonatal prognosis, as far as the development of the respiratory syndrome is concerned, is closely related to the lecithin content of the amniotic fluid.

Preliminary results of investigations by some authors [22, 32] have, moreover, produced evidence that, particulary in some forms of high 
risk pregnancy, there is no parallelism, between the stage of pulmonary maturation and that of somatic and gestational maturation, and that the maturity of the lungs seems to be very important for adaptation to extrauterine life.

It was in order to contribute to the solution of this problem that the present investigation was undertaken: By comparing the most important methods in present day use for estimating gestational age and, thus, indirectly, somatic, organic, biochemical and functional fetal development, with the prognostic value of the methods for estimating pulmonary maturity. The purpose is to give clinical obstetricians the possibility of arriving at a diagnostic and prognostic assessment and a relatively effective therapy using the most effective methods.

\section{i1 Material and methods}

The investigation was carried out in a total of 369 patients with normal pregnancy or pregnancy complicated by maternal or fetal pathology, between 17 and 42 week of gestation.

The group of pathological cases is represented by 26 cases of diabetes ( $A, B$ and $C$ according to WHITE's classification), 39 cases of toxemia and 5 cases of fetal anencephaly.

The investigations consisted of measuring the fetal biparietal diameter (B. D.) by ultrasonic echography, and of the following cytological and biochemical examinations of the amniotic fluid, obtained in each case within 48 hours preceding delivery, by transabdominal or transvaginal amniocentesis: 1 . a percentage calculation of orange-stained cells; 2 . determination of $\triangle \mathrm{OD} 450 \mathrm{~nm}$ for bilirubin; 3. creatinine level; 4. determination of pulmonary surfactant, which was carried out in 199 cases by determining the lecithin/sphingomyelin ratio (L/S r.) with GLUCK's chromatographic technique, in 37 cases by the semiquantitative assay with CLEMENT's foam test (F. T.), and in 135 cases by both methods.

These parameters were correlated with the estimated week of pregnancy.

In agreement with literary data, the calculated 36th week of gestation was conventionally taken as an expression of gestational maturity; the corresponding values of the parameters examined which are regarded as an expression of maturity have been established as $8.7 \mathrm{~cm}$ for the B. D.; $10 \%$ for the number of, orange-stained cells; 0 for $\triangle \mathrm{OD} 450 \mathrm{~nm} ; 1.8 \mathrm{mg} \%$ for creatinine; $\mathrm{L} / \mathrm{S}$ r. $\geqq 2$, or positive $\mathrm{F}$. $\mathrm{T}$. for determining pulmonary maturity. In the 135 cases in which the analysis of pulmonary maturity was carried out by both methods, only the result of L/S r. was taken into consideration.

Finally, each parameter investigated was correlated with the degree of neonatal respiratory distress syndrome (RDS) and mortality.

\section{Results and discussion}

Figure 1 represents the distribution of fetal B. D. values in relation to gestational age.

It can be seen that there is no perfect correspondence: in fact, there are $13.7 \%$ false positive results ("false positive" = B. D. $8.7 \mathrm{~cm}$ or more in pregnancies of less than 36 weeks); and $5.1 \%$ false negative results (B. D. values less than $8.7 \mathrm{~cm}$ in pregnancies of 36 weeks and more) the total of false results being $9.3 \%$.

Furthermore in diabetes there is evidence for precocious somatic development as compared with the mean, shown particulary by the absence of false negative results.

Figure 2 shows the distribution of the amniotic fluid creatinine content in $\mathrm{mg} \%$ in relation to gestational age.

It can be seen that also for creatinine there is no perfect correspondence; the percentage of false positives (i. e. 1.8 or more prior to the 36th week) is $13.7 \%$, and of false negatives (values below 1.8 from week 36 onwards) $14.6 \%$, the total percentage being $14.2 \%$.

Thus, the margin of error in this method exceeds that of the preceding one, especially as far as false negative results are concerned.

Figure 3 represents the distribution of percentage values of orange-stained cells in the amniotic fluid in relation to gestational age.

With this method, the incidence of false positives is hardly $1.3 \%$, of false negatives $27.6 \%$, the total incidence of false results being $20.5 \%$. It can be seen that with this method the margin of error is still larger, but almost exclusively for the false negatives; positivity of this index, on the 


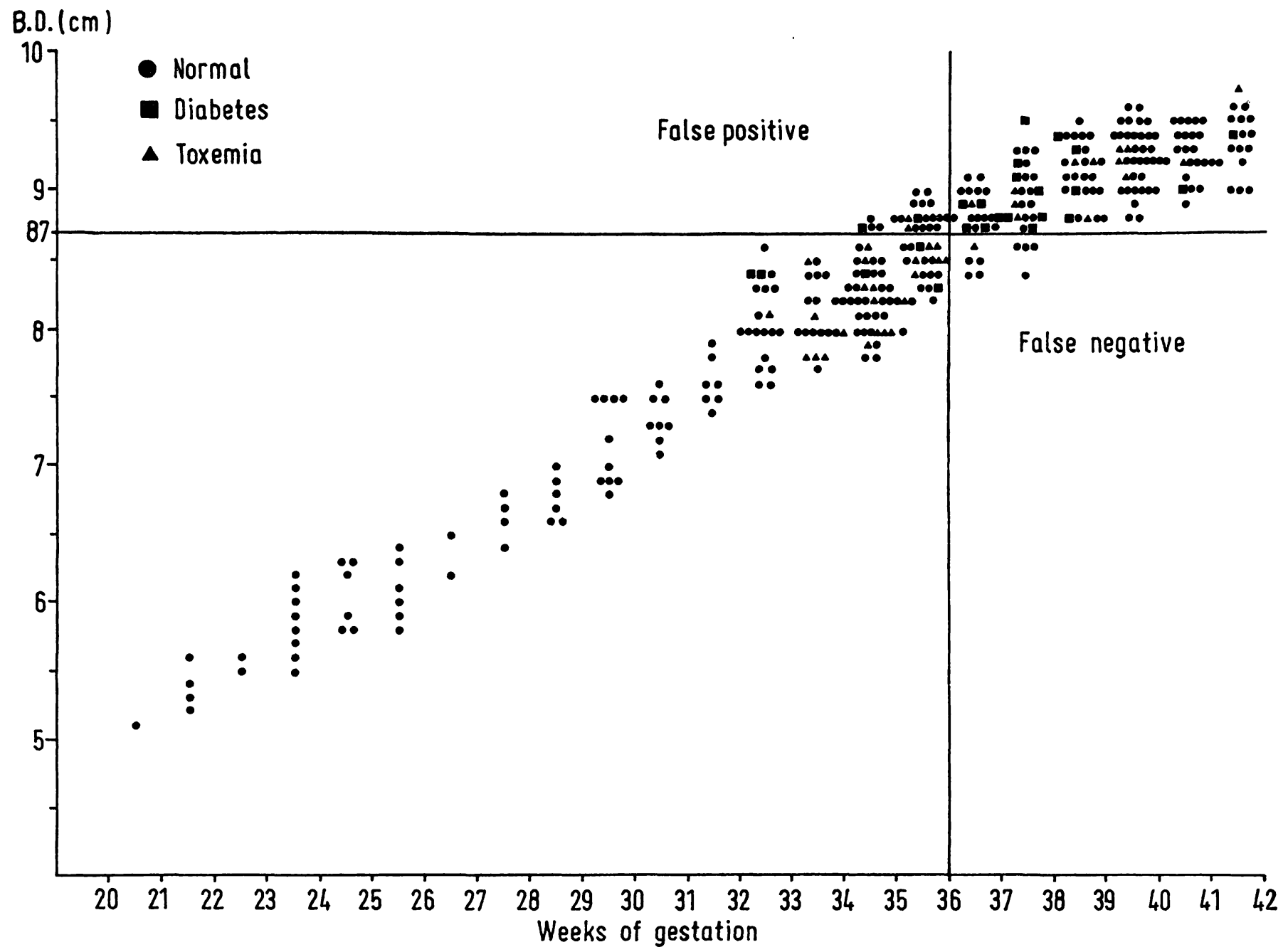

Fig. 1. Biparietal Diameter (cm) correlated with weeks of gestation.

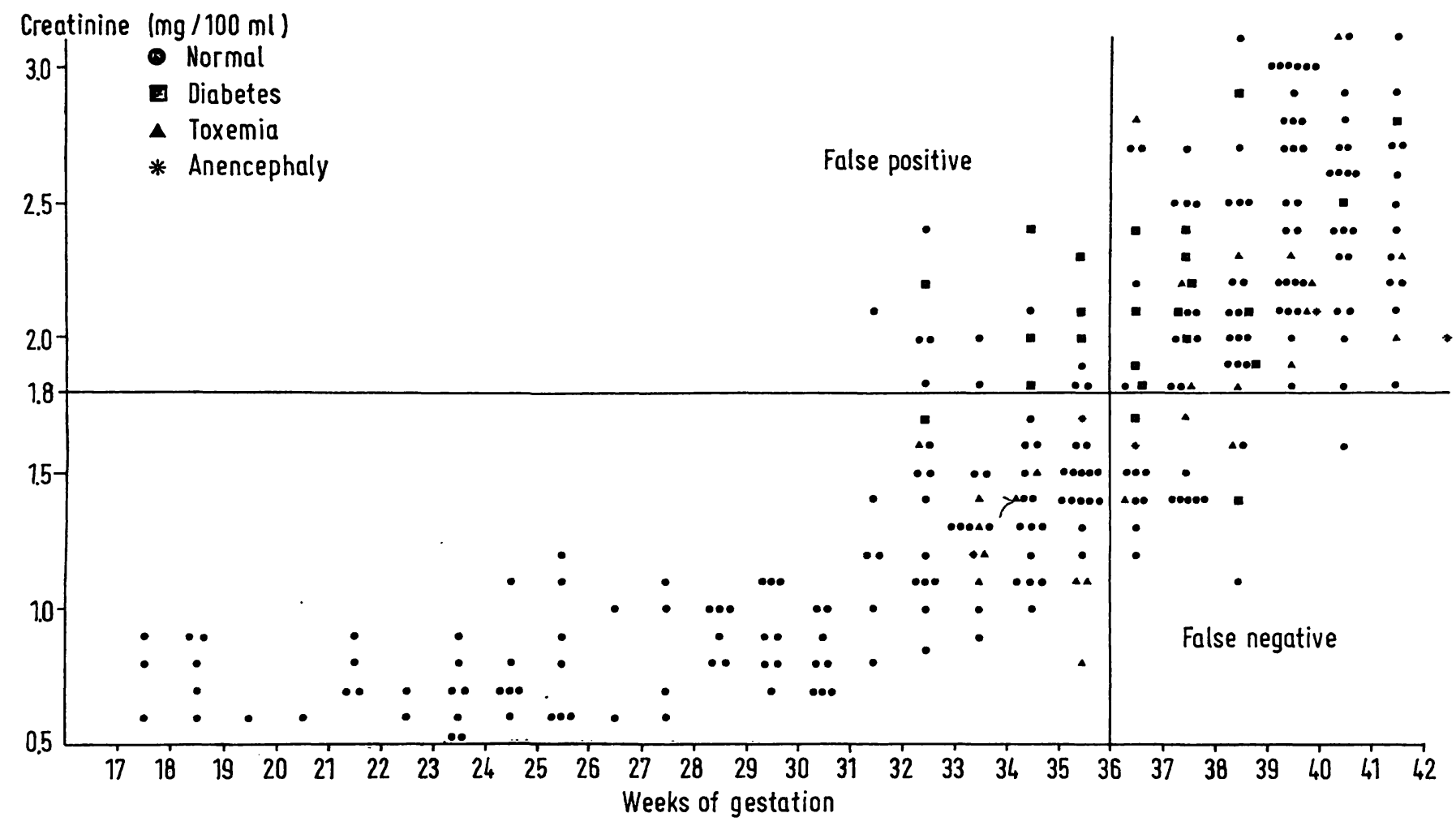

Fig. 2. Creatinine levels (mg per cent) in amniotic fluid correlated with weeks of gestation. 
Fat cells $(\%)$

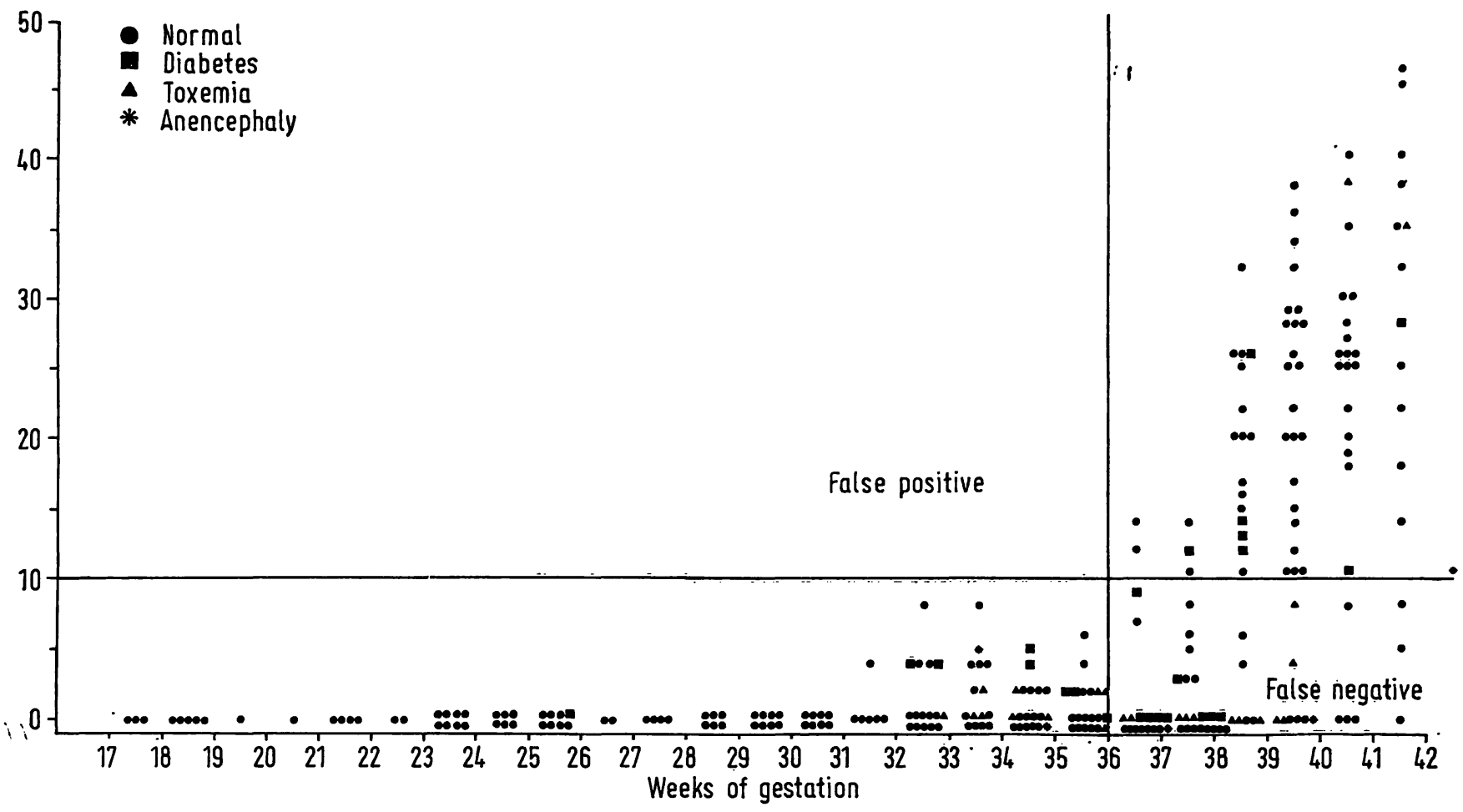

Fig. 3. Fat cells (\%) in amniotic fluid correlated with weeks of gestation.

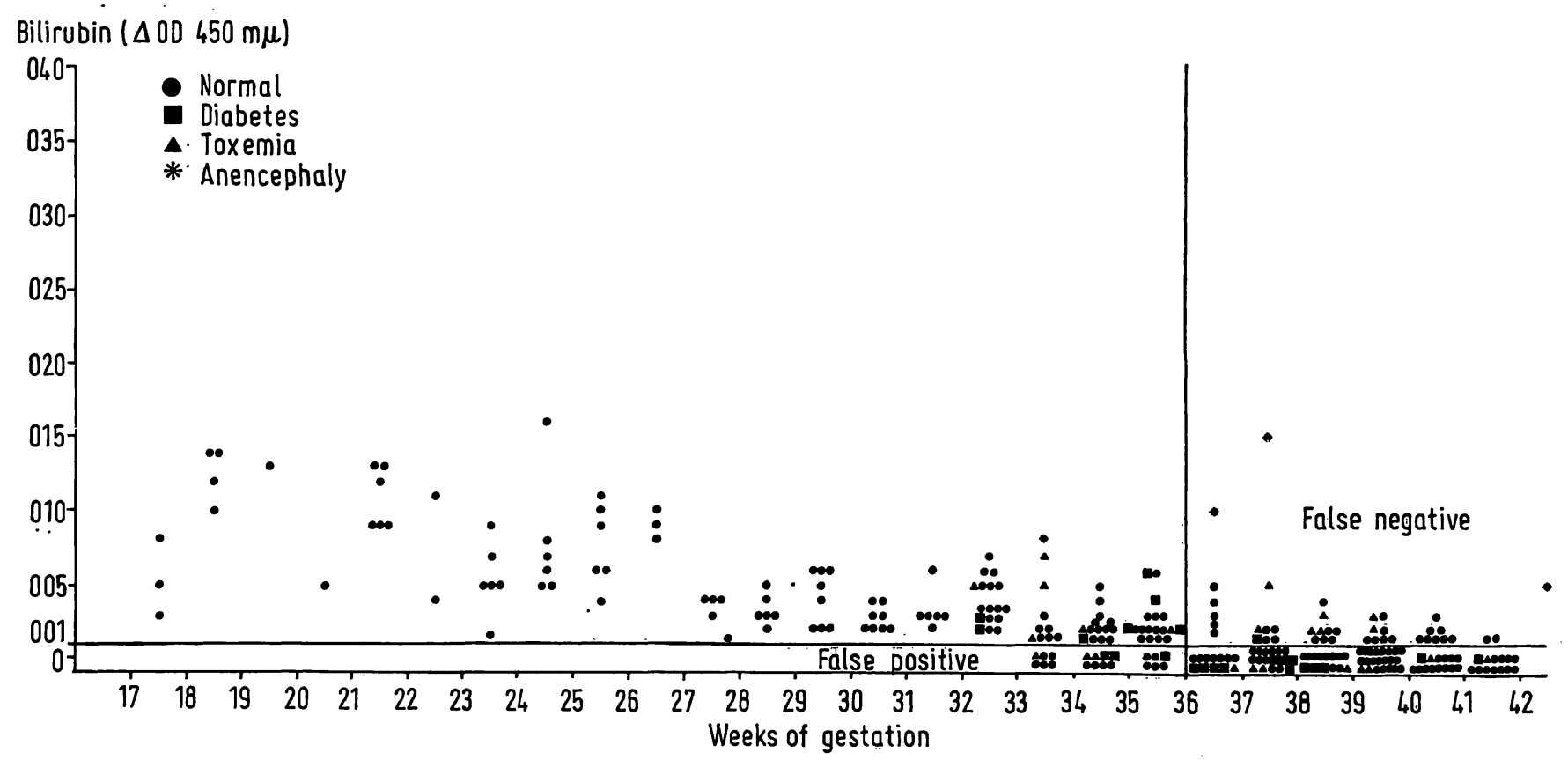

Fig. 4. Bilirubin content in amniotic fluid $(\triangle \mathrm{OD} 450 \mu \mathrm{m})$ correlated with weeks of gestation.

other hand, shows a remarkable agreement with the stage of gestational maturity.

Figure 4 presents the distribution of values of $\Delta \mathrm{OD} 450 \mathrm{~nm}$ in the amniotic fluid in relation to gestational age.
The incidence of false positives is $17.7 \%$, of false negatives $25.1 \%$, total $22.3 \%$.

Thus the method is the least precise for estimating gestational age since it has the highest margins of error both in the positive and the negative cases. 
Tab. I. Absolute and per cent incidence of falses, relative to each method.

\begin{tabular}{|c|c|c|c|c|}
\hline & N. & $\begin{array}{l}\text { False positive } \\
<36 \text { wecks }\end{array}$ & $\begin{array}{c}\text { Falsc negative } \\
\geqq 36 \text { weeks }\end{array}$ & Total \\
\hline 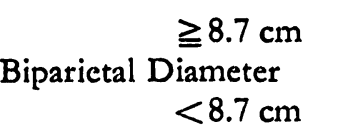 & $\begin{array}{l}168 \\
174\end{array}$ & $23(13.7 \%)$ & $9(5.1 \%)$ & $32(9.3 \%)$ \\
\hline$\triangle O D 450 \mathrm{~nm}=0$ & 113 & $20(17.7 \%)$ & $44(25.1 \%)$ & $64(22.3 \%)$ \\
\hline $\begin{array}{ll} & \geqq 10 \% \\
\text { Fat cells } & <10 \%\end{array}$ & 199 & $1(1.3 \%)$ & $55(27.6 \%)$ & $56(20.5 \%)$ \\
\hline $\begin{aligned} \text { Creatinine } & \geqq 1.8 \mathrm{mg} \% \\
& <1.8 \mathrm{mg} \%\end{aligned}$ & $\begin{array}{l}131 \\
150\end{array}$ & $18(13.7 \%)$ & $22(14.6 \%)$ & $40(14.2 \%)$ \\
\hline $\begin{array}{l}\mathrm{L} / \mathrm{S} \text { ratio } \geqq 2 \text { or } \\
\text { Foam test positive }\end{array}$ & 168 & $24(14.2 \%)$ & & $38(10.8 \%)$ \\
\hline $\begin{array}{l}\mathrm{L} / \mathrm{S} \text { ratio }<2 \text { or } \\
\text { Foam test int. or neg. }\end{array}$ & 181 & & $14(7.7 \%)$ & \\
\hline
\end{tabular}

Table I summarizes the diagnostic value of the methods mentioned above as indices of gestational maturity. It also contains the results of the pulmonary maturity tests.

In classifying the results of the tests of pulmonary maturity the following criterium was used: the whole group was divided into two subgroups of which the first one comprised every case that presented L/S ratio $\geqq 2$ and the cases only evaluated by $F$. $T$. that presented positive result; the second one comprises every case that presented L/S ratio $<2$ and the cases only evaluated by $F$. T. that presented negative or intermediate result.

The analysis of the results shows that, taken absolutely, the best index for estimation is the B. D., followed by the $\mathrm{L} / \mathrm{S}$ ratio and the F. T., then by creatinine, the orange-stained cells, and finally, by the $\triangle O D$.

However, if only the margin of error for the positive values, i. e. those values regarded as indices of gestational maturity, is taken into consideration, it follows that the most correct method is that of the orange-stained cells, followed by the B. D., the creatinine, the pulmonary maturity test, and the $\triangle \mathrm{OD}$; vice versa, for the negative values, the most exact method is the $\mathrm{B}$. D., followed by the pulmonary maturity tests, creatinine, $\triangle \mathrm{OD}$, orange-stained cells.
Tab. II. Relationship between pulmonary maturity tests and RDS and neonatal mortality due to RDS.

\begin{tabular}{lccc}
\hline & N & RDS & Mortality \\
\hline $\begin{array}{l}\text { L/S ratio } \geqq 2 \text { or } \\
\text { Foam test } \\
\text { positive }\end{array}$ & 165 & $2(1,2 \%)$ & $1(0.6 \%)$ \\
$\begin{array}{l}\text { L/S ratio }<2 \text { or } \\
\text { Foram test int. } \\
\text { or neg. }\end{array}$ & 73 & $23(31.5 \%)$ & $16(21.9 \%)$ \\
\hline
\end{tabular}

Taken absolutely, however, the echographic measurement of the fetal $\mathrm{B}$. D. seems to give the most valid results when estimating gestational maturity of the fetus.

Table II represents the results obtained by correlating the two methods for determining fetal pulmonary development and the behaviour of the newborn with regard to the possible development of the RDS and mortality.

The negligible incidence of RDS and mortality in the group which has reached pulmonary maturity, and the greater incidence in the not yet mature group is evidence of the prognostic value of these methods.

When these results are confronted with those emerging from a comparison of other methods for testing fetal maturity with neonatal behaviour (RDS and mortality), (Tab. III) it is seen that 
Tab. III. Gestational age and pulmonary maturity tests correlated with RDS and mortality due to RDS.

\begin{tabular}{|c|c|c|c|c|c|c|}
\hline & & N. & RDS & $\%$ of total & $\begin{array}{l}\text { Mortality } \\
\text { : N. }\end{array}$ & $\%$ of RDS \\
\hline Biparietal & $\underset{\text { diameter }}{\geqq 8.7 \mathrm{~cm}}$ & 150 & $5(3.3 \%)$ & $(2.6 \%)$ & 4 & $(80 \%)$ \\
\hline & $<8.7 \mathrm{~cm}$ & 73 & $19(26 \%)$ & $(16.4 \%)$ & 12 & $(63.1 \%)$ \\
\hline$\triangle \mathrm{OD} 450$ & $\begin{array}{l}=0 \\
\mathrm{~nm}\end{array}$ & 109 & $8(7.3 \%)$ & $(5.5 \%)$ & 6 & $(75 \%)$ \\
\hline & $>0$ & 86 & $15(17.4 \%)$ & (11.6\%) & 10 & $(66.6 \%)$ \\
\hline Fat cells & $\geqq 10 \%$ & 76 & $2(2.6 \%)$ & $(1.3 \%)$ & 1 & $(50 \%)$ \\
\hline & $<10 \%$ & 115 & $22(19.1 \%)$ & $(13 \%)$ & 15 & $(68.2 \%)$ \\
\hline Creatinine & $\geqq 1.8 \mathrm{mg} \%$ & 132 & $8(6.1 \%)$ & $(3 \%)$ & 4 & $(50 \%)$ \\
\hline & $<1.8 \mathrm{mg} \%$ & 59 & $16(27.1 \%)$ & (13.5\%) & 8 & $(50 \%)$ \\
\hline $\begin{array}{l}\text { L/S ratio } \\
\text { Foam test } \\
\text { L/S ratio }\end{array}$ & $\begin{array}{l}\geqq 2 \text { or } \\
\text { positive } \\
<2 \text { or }\end{array}$ & 165 & $2(1.2 \%)$ & $(0.6 \%)$ & 1 & $(50 \%)$ \\
\hline Foam test & int. or neg. & 73 & $23(31.5 \%)$ & (21.9\%) & 16 & $(69.5 \%)$ \\
\hline
\end{tabular}

Tab. IV. Average gestational week in which pulmonary maturity is reached in normal and pathological pregnancies.

\begin{tabular}{lc}
\hline & Average \pm s. d. \\
\hline Normal pregnancies & $35.8 \pm 1$ \\
Diabetes & $37.2 \pm 0.8$ \\
Toxemia & $34.4 \pm 0.5$ \\
Rh isoimmunization & $36.2 \pm 0.7$ \\
Premature membrane rupture & $35.3 \pm 0.9$ \\
\hline
\end{tabular}

the best prognostic correspondence is found for the pulmonary maturity tests rather than for the tests of gestational maturity.

Table IV shows the average week of gestation at which pulmonary maturity is reached in normal cases and in some pathological pregnancies.

It can be seen how in normal cases about 36 weeks seems to correspond to gestational maturity; on the other hand, in pathological cases the time of fetal pulmonary maturation deviates from what occurs in normal cases, in some cases being earlier, in others later; this would mean a divergence between gestational and pulmonary maturity. This seems to be particularly evident in the case of diabetes, in which somatic maturation would be recorded as precocious [40] when compared with normal cases, a fact which, in some way, is also shown by the B. D. values.
On the other hand, the prognostic value of pulmonary maturity tests, whose superiority to gestational maturity tests has already been shown in a complex analysis, is documented still more clearly if the different groups of pathology are analyzed.

Table V summarizes the results concerning the group of pregnancies complicated by diabetes; only the B. D. has been considered as index of gestational maturity, since it seems, as has been stated before, to be the method suited best for such a purpose.

The divergence is evident between somatic maturity (advanced) and pulmonary maturity (retarded), which is documented by 8 cases with a B. D. $\geqq 8.7 \mathrm{~cm}$ and a L/S r. $<2$; this is reflected in the prognosis, in particular as far as mortality is concerned. It is concluded that pulmonary maturity, and its determination with the aid of the tests is a definitely more valid index for the purpose of a prognostic judgment.

\section{Comment and conclusions}

The conclusions which emerge the results presented here seem to be important for guiding the steps taken by the obstetrician.

Fetal maturity is a complex event, and must therefore be evaluated by combined study of the largest possible number of functions, 
Tab. V. B. D. and pulmonary maturity tests correlated with RDS incidence and mortality due to RDS in pregnancies complicated by diabetes.

\begin{tabular}{lccccc}
\hline & N. & RDS & \% of total & $\begin{array}{c}\text { Mortality } \\
\text { N. }\end{array}$ & \% of RDS \\
\hline B. D. $\geqq 8.7 \mathrm{~cm}$ & 11 & 2 & & 1 & $(50 \%)$ \\
L/S ratio $\geqq 2$ & & $(18.1 \%)$ & $(9.9 \%)$ & & 0 \\
B. D. $\quad<8.7 \mathrm{~cm}$ & 0 & 0 & 0 & 0 & \\
L/S ratio $\geqq 2$ & & & & & \\
B. D. $\geqq 8.7 \mathrm{~cm}$ & 8 & $(25 \%)$ & $(25 \%)$ & & $(100 \%)$ \\
L/S ratio $<2$ & 5 & 5 & $(50 \%)$ & 3 & $(60 \%)$ \\
B. D. $<8.7 \mathrm{~cm}$ & 6 & $(82.2 \%)$ & $(50 \%)$ \\
L/S ratio $<2$ & & & &
\end{tabular}

with the aid of various methods, each of which contributes in its own way. However, a clinical evaluation of such methods shows how one can assign to each of them a different prognostic and diagnostic value, so that it appears clear that ultrasonic echographic measurement of the fetal B. D. is, taken absolutely, the most suitable method, and the one nearest to reality. Next to it, creatinine assays seem to be very useful, whereas the percentage of orange-stained cells and the $\triangle O D$ appear to be subject to gross errors.

Such methods for evaluating gestational age constitute a means for obtaining somewhat indirect indices of the capacity of functional autonomy, of adaption, and of survival of the fetus whenever it is compelled to face the external environment prematurely.

The comparison of these methods with the pulmonary maturity tests, demonstrate that the latter make it possible to obtain higher safety margins. This seems evident not only from the complex analysis of the case material, but also from a select analysis of individual groups of high risk cases (Tab. V).

Moreover, a comparison of normal cases and "high risk" cases shows that in certain pathological conditions, in particular in diabetes and toxemia, there is a deviation of the stage of pulmonary maturation; it is advanced in toxemia and retarded in diabetes. The whole matter assumes great importance if the fact is called to mind that in these circumstances fetal maturation, as determined by the ordinary tests for evaluating the stage of gestation, seems to behave in a reverse manner, as is well demonstrated in the case of diabetes.

The implications of all this for obstetric treatment can easily be guessed.

When it becomes necessary to terminate gestation at a premature stage, one needs data giving the most reliable prognosis for the newborn survival.

Of major importance for this purpose is the determination of the fetal B. D. as an index of somatic development and of the stage of gestation, and the evaluation of fetal pulmonary maturity. Moreover, it becomes evident that the concept of gestational age by itself as an index of the moment of maturation of the fetus as a whole is uncertain in particular situations of pathological pregnancy. It may be concluded, that the highest degree of reliability should be attributed to the tests for assessing pulmonary maturity, which show a more perfect correlation between the data provided by them and the fate of the newborn. 


\section{Summary}

The validity of the assessment of the fetal age and pulmonary maturity was evaluated on 369 patients at various stages of normal pregnancy and complicated by diabetes, toxemia and fetal anencephaly.

Gestational maturity was assessed by ultrasonic measurement of the fetal biparietal diameter (Fig. 1) and by analysing constituents of amniotic fluid (creatinine, bilirubin, fat cells) (Figs. 2-4) while pulmonary maturity was assessed from the $L / S$ ratio in the amniotic fluid. Each individual method had a wide margin of error (Tab. 7), however, ultrasound cephalometry gave the best prediction for determination of fetal age.

In 135 selected cases lung maturity was assessed by using two techniques, a thin layer chromatographic determination of the lecithin/sphingomyelin ratio in the amniotic fluid and a rapid semiquantitative test to determine the titre of surfactant which generates stable foam in presence of ethanol. The results obtained lby the two methods correlated well and were reliable in predicting the respiratory distress syndrome. It appears that these methods make it possible to obtain greater margins of reliability.

The role of fetal and maternal factors in the maturation of fetal lungs was also studied in several pathological conditions and it was noted that in many cases of maternal diabetes mellitus lung maturity was reached at a later age than in normal pregnancies (Tab. IV).

It is concluded that if termination of pregnancy is indicated, the physician should rely more on the assessment of lung maturity than on indicators of gestational age.

Keywords: Bilirubin, creatinine, fat cells, fetal maturity, gestational age, high risk pregnancy, lecithin/sphingomyelin ratio, pulmonal maturity, surfactant, ultrasonographic cephalometry.

\section{Zusammenfassung}

Bestimmung der fetalen Reife und der fetalen Lungen'entwicklung durch kombinierte Methoden

Bei 369 Patientinnen mit normalen und durch Diabetes mellitus, Gestose sowie fetale Anenzephalie komplizierten Schwangerschaften verschiedener Gestationsdauer wurde die Zuverlässigkeit der Bestimmungsmethoden des fetalen Alters und der Lungenreife überprüft. Die Reife nach Gestationsdauer wurde durch die Messung des biparietalen Kopfdurchmessers (Fig. 1) und durch die Analyse von Fruchtwasserbestandteilen (Kreatinin, Bilirubin, FettZellen) (Figs. 2-4) bestimmt, während die Lungenreife durch den L/S-Quotienten im Fruchtwasser festgelegt wurde. Jede einzelne Methode hatte eine große Fehlerbreite (Tab. I). Die Ultraschall-Kephalometrie jedoch ergab die beste Voraussage bei der fetalen Altersbestimmung.

Bei 135 ausgewählten Fällen wurden die Lungenreife mit Hilfe von 2 Methoden bestimmt, einmal durch dünnschicht-chromatographische Bestimmung des Lecithin/ Sphingomyelin-Quotienten im Fruchtwasser und zum anderen durch einen schnellen, semiquantitativen Test, bei dem der Titer des surfactant bestimmt wird, der einen stabilen Schaum in Gegenwart von Ätanol bildet. Die durch die beiden Methoden erzielten Resultate korrelierten gut miteinander und waren zuverlässig hinsichtlich der Voraussage eines Atemnotsyndroms. Offenbar ermöglichen diese Methoden eine Erweiterung des Vertrauensspielraumes. Darüber hinaus wurde der Einfluß fetaler und mütterlicher Faktoren auf die fetale Lungenreifung unter verschiedenen pathologischen Bedingungen analysiert. Dabei konnte festgestellt werden, daß in vielen Fällen eines mütterlichen Diabetes mellitus die Lungenreife im Vergleich zu normalen Schwangerschaften zu einem späteren Zeitpunkt eintritt (Tab. IV).

Aus all diesem wird der Schlu $\beta$ gezogen, da $\beta$ in den Fällen, in denen eine Schwangerschaftsbeendigung indiziert ist, der Arzt sich mehr auf die Bestimmung der Lungenreife verlassen sollte und weniger auf die Parameter der Gestationsdauer.

Schlüsselwörter: Bilirubin, fetale Reife, Fett-Zellen, Gestationsalter, Kephalometrie, Kreatinin, Lecithin/SphingomyelinQuotient, pulmonale Reife, Risikoschwangerschaften, surfactant, Ultraschall.

\section{Résumé}

Determination de la maturité foetale et du developpement des poumons du foetus a l'aide de methodes combinées

On a étudié, en comparant plusieurs méthodes, la validité de l'estimation de l'âge foetal et de la maturité pulmonaire sur 369 patientes représentant différents stades de grossesse soit normale, soit compliquée par diabète, toxémie et anencéphalie foetale. La maturité gestationnelle a été évaluée par le mesurage ultrasonographique du diamètre bi-pariétal de la téte foetale (Fig. 1) et par l'analyse des constituants du liquide amniotique (créatinine, bilirubine, cellules oranges) (Figs. 2-4), tandis que la maturité pulmonaire a été évaluée par la recherche du „,surfactant', dans le liquide amniotique. Chaque méthode prise en particulier a démontré une marge d'erreur élevée (Tab. I), bien que la céphalométrie ultrasonographique ait donné les meilleures indications pour l'âge foetal. Dans les 135 cas sélectionnés, l'évaluation du développement pulmonaire a été déterminée par deux techniques: l'une, la détermination chromatographique du rapport lécithine/sphingomyéline, l'autre, un test semi-quantitatif qui permet de déterminer le titre de surfactant qui engendre de l'écume stable en présence d'éthanol. Il est très facile de confronter les résụltats obtenus par les deux méthodes, 
ces résultats s'avérant très utiles pour prédire le syndrome de détresse respiratoire.

Les recherches sur la valeur diagnostique et prognostique des tests de maturité pulmonaire semblent confirmer la possibilité d'obtenir de plus grandes marges de sécurité grâce à ces méthodes.

Le rôle des facteurs maternels et foetaux dans la maturation du poumon foetal a été étudié aussi dans différentes con- ditions pathologiques et on a remarqué que dans plusierus cas de diabète la maturité pulmonaire a été atteinte à un âge plus tardif que dans les cas normaux (Tab. IV). On a conclu que dans le traitement de ces cas, lorsque l'interruption de la grossesse est indiquée, le médecin doit compter davantage sur les méthodes d'évaluation de la maturité pulmonaire que sur celles déterminant l'âge de gestation.

Mots-clés: âge de gestation, bilirubine, cellules oranges, cephalométrie ultrasonographique, creatinine, grossesse à risque élevé, maturité foetale, maturité pulmonaire, rapport lécithine/sphingomyéline, surfactant.

\section{Bibliography}

[1] Anderson, A. B. M., A. D. Griffrths: Estimation of duration of gestation by amniotic fluid cytology. $\mathrm{J}$. Obstet. Gynaec. Brit. Cwlth. 75 (1968) 300

[2] Andrews, B. F.: Amniotic fluid studies to determine fetal maturity. Pediat. Clin. N. Amer. 17 (1970) 49

[3] Barnett, H. R., M. Nevin: The value of the Nile blue test in estimating fetal maturity in normal and complicated pregnancies. J. Obstet. Gynaec. Brit. Cwlth. 77 (1970) 151

[4] Bernstine, M. L.: Physiology of the fetal urinary tract. Clin. Obstet. Gynec. 13 (1970) 652

[5] Bhagwani, S. G., D. Fahny, A. C. Turnbull: Prediction of neonatal respiratory distress by estimation of amniotic fluid lecithin. Lancet (1972) I, 159

[6] Boog, G., M. Irrman, J. Vogt: Fetal cephalometry by ultrasound. II. Its advantage in obstetrical treatment. Rev. Franc. Gynéc. 64 (1969) 311

[7] Brosens, I., H. Gordon: The estimation of maturity by cytological examination of the liquor amnii. J. Obstet. Gynaec. Brit. Cwlth. 73 (1966) 88

[8] Brosens, I., H. J. Gordon, A. Baert: Prediction of fetal maturity with combined cytological and radiological methods. J. Obst. Gynaec. Brit. Cwlth. 76 (1969) 20

[9] Brown, A. H.: Constituents of amniotic fluid: reflections on normal and abnormal fetal maturation. In: AdAmson, K.: Diagnosis and treatment of fetal disorders. Springer, New York 1968

[10] Campbell, S.: An improved method of fetal cephalometry by ultrasound. J. Obstet. Gynec. Brit. Cwlth. 75 (1968) 568

[11] Ceccarello, P. L., A. Capozzi, F. Zisa, G. Cubesi, A. IAnNiruberto, F. Destro: Test di maturità polmonare fetale e prognosi neonatale in gravidanze normali e a rischio. (Nota 3) Ann. Obstet. Ginec. Medicina Perinatale 1973

[12] Cherry, S. H.: Amniotic fluid bilirubin as an index of fetal maturity. Obstet. Gynec. 30 (1967) 615

[13] Chowdhury, N. N., K. C. DE, A. K. Mukherjee: Diagnostic value of creatinine content of amniotic fluid in determination of fetal maturity. Calcutta Medj. 66 (1969) 98

[14] Clements, J. D., A. C. G. Platsker, D. F. Tierney, C. J. Hobel, R. K. Creasy, W. J. Margolis, D. W. Thrbeault, W. H. Tooley, W. OH: Assessment of the risk of the respiratory distress syndrome by a rapid test for surfactant in amniotic fluid. New. Engl. J. Med. 286 (1972) 1077

[15] Destro, F., A. Ianniruberto, A. Capozzi: Metodi combinati per la valutazione dell'alto rischio fetale: estroluria, cefalometria fetale ultrasonica, ricerche biochimiche e citologiche sul liquido amniotico. Minerva ginec. 24 (1972) 293

[16] Dewhurst, C. J., J. M. Beazley, S. Cambell: Assessment of fetal maturity and dysmaturity. Amer. J. Obstet. Gynec. 113 (1972) 141

[17] Donovan, A. J., T. J. Ciacco, B. F. Andrews, W. M. Jr. Wolfe: Determination of fetal maturity by spectrophotometric creatinine and cytologic study of the amniotic fluid. Submitted to Amer. J. Obstet. Gynec.

[18] Doran, T. A., S. Bjerre, C. Porter: Creatinine uric acid and electrolytes in amniotic fluid. Amer. J. Obstet. Gynec. 106 (1970) 325

[19] Dumont, M., J. Lansac, Y. Page: The value of amniotic fluid creatinine assay in the estimation of fetal age. Rev. Franc. Gynéc. 66 (1971) 193

[20] Fennefrohn, B.: The usefulness of cytological and spectrophotometric analyses of the amniotic fluid for establishing the degree of maturity of the child. $\mathrm{Zbl}$. Gynäk. 92 (1970) 1257

[21] Field, S. H., E. K. Smith, H. S. Readon: Dissimilarities in the respiratory distress syndrome of infants of diabetic and nondiabetic mothers. Proc. Amer. Soc. (1963) 38

[22] Foulds, J. W., C. A. Pennock: Amniotic fluid creatinine: an unreliable index of fetal maturity. Submitted to J. Obstet. Gynaec. Brit. Cwlth.

[23] Gluck, L., V. Kulovich, R. C. Borer, R. H. BrenNer, G. G. Anberson, W. N. Spellacy: Diagnosis of the respiratory distress syndrome by amniocentesis. Amer. J. Obstet. Gynec. 109 (1971) 440

[24] Gluck, L.: Pulmonary surfactant and neonatal respiratory distress. Hosp. Pract. 6 (1971) 456

[25] Gluck, L.: Letters to the Editor. Pediatrics 49 (1972) 464

[26] Gluck, L.: Biochemical development of the lung: clinical aspects of surfactant development, RDS and the intrauterine assessment of lung maturity. Clin. Obstet. Gynec. 14 (1971) 710 
[27] Harding, P., A. Spence: Significance of maternal creatinine clearance in assessing feto-placental function. Amer. J. Obstet. Gynec. 106 (1970) 333

[28] Henneman, C. E., G. V. Anderson, A. Tejavej, H. A. Gross, M. L. Heiman: Fetal maturation and amniotic fluid. Amer. J. Obstet. Gynec. 108 (1970) 302

[29] Ianniruberto, A.: L'uso diagnostico degli ultrasuoni in Ostetricia e Ginecologia. Arch. Ostet. Ginec. 1 (1970) 39

[30] Ianniruberto, A., F. Destro, F. Zisa, A. Capozzi, S. PARISI: A new test for the rapid evaluation of foetal lung maturity (Note I). Minerva Ginec. 24 (1972) 566

[31] Ianniruberto, A., F. Destro, A. Capozzi, F. Zisa, S. PARISI: Comportamento dei tests di maturità polmonare in gravidanze normali e a rischio (Note II). Ann. Ost. Gin. Med. Perin. 1972

[32] Ianniruberto, A., J. M. Gibbons Jr.: Predicting fetal weight by ultrasonic B-scan cephalometry. An improved technique with disappointing results. Obstet. and Gynec. 37 (1971) 689

[33] JoRring, K.: Maturity determination in the last trimester of pregnancy. Int. J. Obstet. Gynaec. 8 (1970) 58

[34] Kornacki, T., B. Biczysko: Amniotic fluid creatinine values of fetal distress. Pol. Med. J. 5 (1966) 601

[35] Nakamura, J., J. F. Roux, R. G. Brown, A. Y. SwEET: Total lipids and the lecithin-sphingomyelin ratio of amniotic fluid: An antenatal test of lung immaturity. Amer. J. Obstet. Gynec. 113 (1972) 363

[36] Nelson, G. H.: Amniotic fluid phospholipids patterns in normal and abnormal pregnancies. Amer. J. Obstet. Gynec. 105 (1969) 1072

[37] Nelson, G. H.: Relationship between amniotic fluid lecithin concentration and respiratory distress syndrome. Amer. J. Obstet. Gynec. 112 (1972) 827
[38] Prtkin, R. M., S. J. Zwrrek: Amniotic fluid creatinine. Amer. J. Obstet. Gynec. 98 (1967) 1135

[39] Russel, J. G. B., R. G. Rangecroft: The effect of fetal and maternal factors on radiological maturation of the fetus. J. Obstet. Gyneac. Brit. Cwlth. 76 (1969) 479

[40] Sharma, S. D., R. R. Trussel: The value of amniotic fluid examination in the assessment of fetal maturity. J. Obstet. Gynaec. Brit. Cwlth. 77 (1970) 215

[41] Thompson, H. E., E. Makowskr: Estimation of birth weight and gestational age. Sixth World Congress Gynec. Obstet. 1970

[42] Underhill, R. A., J. M. Beazley, S. Campbell: Comparison of ultrasound studies in patients with unknown confinement dates. Brit. med. J. 3 (1971) 736

[43] Votta, R. A., D. Bobrow, C. Gagneten, O. Rarada, M. Grulletrr: Cytologic study of amniotic fluid in pregnancy. Amer. J. Obstet. Gynec. 102 (1968) 517

[44] VRettos, A. S., C. Kolmopoulos, N. Daskalakis, P. P. Panayotou: L'age de la gestation. Sa determination par l'axamen du liquide amniotique. J. Gyn. Obst. Biol. Repr. 1 (1972) 4

[45] White, C. A., D. E. Doorenbos, J. T. Bradbury: Role of chemical and cytological analysis of amniotic fluid determination of fetal maturity. Amer. J. Obstet. Gynec. 104 (1969) 664

[46] Whitfield, C. R., W. H. Chan, W. B. Sproule, A. D. Stewart: Amniotic fluid lecithin-sphingomyelin ratio and fetal lung development. Brit. med. J. 2 (1972) 85

[47] WILlOCKs, J.: Serial cephalometry by ultrașound as an index of fetal growth and well-being. Sixth World Congress Gynec. Obstet. 1970

[48] WrLlocks, J.: The study of fetal growth by serial cephalometry and estriol measurements. J. Reprod. med. 6 (1971) 84
Prof. Dr. Filippo Destro Divisione di ostetricia e ginecologia Ospedale Civile Via Vittorio Veneto 171 I-34170 Gorizia/Italy 